\title{
The Dreams of Archaeology
}

\section{Alexandra Warwick}

One of the most interesting recurrent tropes in the writings of archaeologists, as well as in the fictions of archaeology is the dream. Baron Denon ${ }^{1}$ writes of Karnac in 1802:

The imagination is fatigued with the mere thought of describing [these ruins] [. . .] to form a competent idea of so much magnificence it is necessary that the reader should fancy what is before him to be a dream, for even the spectator cannot believe his eyes. (qtd. in Ceram 122)

In A.H. Layard's 1854 account of his excavations at Nineveh he writes:

We look around in vain for any traces of the wonderful remains we have just seen, and are half inclined to believe we have dreamed a dream, or have been listening to some tale of Eastern romance. Some, who may hereafter tread on the spot when grass grows again over the ruins of the Assyrian palaces, may indeed suspect I have been relating a vision. (Popular 311)

Some seventy years later Howard Carter describes covering up the sealed doorway that has been found in the Valley of the Kings:

The tomb had vanished. So far as the appearance of the ground was concerned there never had been any tomb, and I found it hard to persuade myself at times that the whole episode had not been a dream. (91)

And in one of the fragments that make up Walter Benjamin's Arcades Project:

The dream - it is the earth in which the find is made that testifies to the primal history of the nineteenth century. (88)

Denon's comment makes explicit what is registered in the others: the inadequacy of empirical observation in the comprehension of archaeological sites, and the inevitability, even the necessity, of recourse to the dream rather than to the deliberately observed reality. The pull of the poetic away from the empirical is apparent: in Denon, Layard, Carter and many others the moments of doubt about reality are breaks in what are often long, dense and prosaic catalogues of distances travelled, buckets of earth removed, dimensions of objects measured and difficulties in obtaining labour and transport.

Benjamin's fragment gestures at the complexity of the archaeological imagination in the nineteenth century. Yet the referent isn't clear: is the dream the ground in which the find is made, or is it a dream that there could be such earth that would yield such finds? The earth itself is the witness that would seem to 'testify' rather than, as is more usually the case, the speaking object, the find. At the same time, there is tension too in Benjamin's juxtaposition of the very specific 'nineteenth century' and the vague, mythical 'primal history', the latter phrase appearing decidedly unscientific against the new terminology of the emerging discipline of 
archaeology. No doubt the use of the term 'primal' here has much to do with that other collector and contemporary of Benjamin, Sigmund Freud, for whom it signified both an individual and collective originary. Significantly, the archaeological collection that Freud himself started in 1896 was a continuation of his earlier interests; as a young man he had been fascinated by Heinrich Schliemann's excavations of Troy. He said that Schliemann's life was the one that he most envied (Gay 172) and remarked in a letter of 1931: "I have sacrificed a great deal for my collection of Greek, Roman and Egyptian antiquities, [and] have actually read more archaeology than psychology" (Letters 403). This analogy between psychoanalysis and archaeology is one that has been much discussed by Freudian scholars. Donald Kuspit, for example, makes a substantial claim for its importance, stating: "It is not simply a dramatic device to enliven and adorn the discourse of psychoanalysis [. . .] but the major instrument of its self-understanding' (133). This is certainly not a position shared by all Freud scholars and the significance of the metaphor remains something of a contested point among them, ${ }^{2}$ but the entanglement of psychoanalysis and archaeology has persisted in both popular and critical thought.

Rosalind Williams indicates the difficulty of reading past the gravitational pulls of particular ideas such as these. Of Freud (and Marx), she observes that they "depend so much upon subterranean imagery that it is now virtually impossible to read a text about the underworld without [. . .] reading the buried world as the subconscious, or the working class, or both" (42). The difficulty that Williams alludes to is that the persuasiveness of Freud's analogy has tended to encourage the development of only one form of mediation between its terms, in which psychoanalysis is persistently used to read archaeology, but archaeology less frequently used to read psychoanalysis. As such it elides something of the possibility of recovering the historical conditions out of which psychoanalytical forms of thought themselves emerged. In particular, if psychoanalysis is in part produced through the elaboration of a particular conception of time and space, it is already possible to see that conception as present within (and in some sense conditioned by) the archaeological imagination. While, then, Freudian ideas continue to inform our own contemporary re-presentations of nineteenth-century phenomena, the historical dynamics of this dialectic are rendered more complex once we begin to recognise the extent to which such ideas are themselves structured through distinctively nineteenthcentury tropes and cultural forms. In saying this, I am suggesting that it isn't necessary to try to read 'past' the ideas of Marx and Freud, but that the investigation of their development coincident with that of archaeology may be revealing of their relations with each other, and of the appearances of the archaeological in nineteenth-century fiction.

Writing in 1985, Robert Young observed that "at the heart of its science we find a culture's values," (125) and since the 1980s the study of the history of science, literature and culture has been enriched by the consideration of the complex interrelations that exist between them. Archaeology, like many other sciences, 'emerges' during the nineteenth century, through its separation from antiquarianism, tracking a familiar path to a place as a professionalised and bounded discipline. As with other Victorian sciences, what is often interesting in archaeology is thus the "remnant of the mythical" (Beer 2). that persists within the movement towards apparently objective study. This article endeavours to suggest that while the dream would seem to be just such a mythic remnant in archaeological writings, what it actually indicates is a troubled engagement with the historical present as Victorian culture attempts to comprehend the conditions of capitalist modernity. Specifically, the appearance of the 
dream in these texts stands in place of a discussion of the nature of the commodity and of the labour that has produced it.

\section{Stratigraphic and Artefactual Fictions}

Although there is a prior existence of what might perhaps better be called an archaeological curiosity, ${ }^{3}$ the emerging science of archaeology in the nineteenth century is shaped in very particular ways by its contemporary cultural context. Julian Thomas points out that archaeology inherits certain conceptual and linguistic resources that structure its expression, but also that, in turn, archaeology becomes "the source of many of the metaphors through which the modern imagination has sought to understand the world" (169). One of the cultural notions that archaeology both inherits and propagates in a particular modern formulation is that of the spatial relationship between surface and depth. Hence, Thomas argues that:

The past is automatically connected with stratigraphic depth, and needs to be drawn back from darkness and obscurity if it is to be a source of significant knowledge [. . .] this disciplinary orientation towards depth, concealment, mystery and revelation is quite obstructive, for it enhances the belief that the past is entirely separate from the present: it is 'somewhere else' that has to be accessed in a particular way [. . . ] a substance that is secreted in dark places awaiting its recovery. (170)

This, of course, is suggestive of the emblematic 'somewhere else' of the late nineteenth century: the unconscious as described by Freud. Indeed, Freud's use of archaeology as an analogy for psychoanalysis is present from his earliest work onwards. The long passage from "The Aetiology of Hysteria" (1896) that begins "Imagine that an explorer arrives in a little-known region where his interest is aroused by an expanse of ruins" ("Hysteria" 192) is probably the best known of the many examples from his writing. Here Freud states directly that "the fact that the scenes [incidents] are uncovered in a reversed chronological order" is "a fact which justifies our comparison of the work with the excavation of a stratified ruined site" ("Hysteria" 198). Thirty years later in "Civilization and its Discontents" (1930) Freud is still drawing upon the analogy, in this case through an extended comparison of Rome, with its evidence of successive layers of occupation, to the structure of the psyche.

The form of the 'mighty metaphor', as Kuspit and others understand it, is a fairly specific one. In spite of his collection of antiquities, for Freud it is not so much about the artefacts as about the process, which at its simplest level is digging. In the "Imagine that an explorer" passage he contrasts two approaches. The explorer "may content himself with inspecting what lies exposed to view, with questioning the inhabitants" or:

He may have brought picks, shovels and spades with him, and he may set the inhabitants to work [. . . ] together with them he may start upon the ruins, clear away the rubbish, and, beginning from the visible remains, uncover what is buried. ("Hysteria" 192)

This shows that the psychoanalytic version of archaeology is one principally governed by an idea of layering, of strata and sedimentation, and of the heroic work of digging. In the unquestioned right to "set the inhabitants to work" it also registers the colonial assumptions of many of the archaeological enterprises of the nineteenth century. 
These particular emphases are perhaps derived from his long fascination with Schliemann. Schliemann's excavation of Troy in the 1870 s depended on a very specific idea of what he was doing: digging down to find the truth of the existence of the Homeric city. In his own words: "As it was my object to excavate Troy, which I expected to find in one of the lower cities, I was forced to demolish many interesting ruins in the upper strata" (Schliemann 28). As Schliemann bases his digging on Homer, so Freud's image of the work of psychoanalysis is similarly inflected and guided by a trust in the evidential value of classical literature, as we see in his use of the drama of Oedipus. Freud's use of the term 'stratified' is similarly significant, in so far as it signals the scientific claims of his fledgling discipline, but also draws on what was by then an important interpretative device.

Originating in geology, the dominant science of the early nineteenth century, the idea of the stratigraphic column was firmly established by 1800 . As Rosalind Williams notes: "the image of the column - vertical sections in the earth, corresponding to enormously long periods of time - became the central representation of deep time." Equally, she suggests that despite the image appearing to represent a triumph of empirical observation, "in other respects it opened the way to the mythological" (29). In Freud's case, it also opens the way to the metaphorical, and the conflation of depth, profundity, truth and the past; emphasising an idea that anything already visible cannot be a source of significant knowledge (Thomas 169-70). Thomas notes, too, that the stratigraphical approach is most closely associated with "culture history," with the desire to recover a whole past (160). This desire is one often translated into the dream.

Thinking in this way, we might begin to draw some categories in the broad field of what could be called archaeological fictions. In 'stratigraphic' fiction we can see a version of the historical novel in which the entire action is set in an identifiable period of the more distant past. In the nineteenth century these are works like Edward Bulwer-Lytton's The Last Days of Pompeii (1834), Charles Kingsley's Hypatia (1853), John Henry Newman's Callista (1855) or Walter Pater's Marius the Epicurean (1885). The motivations for these are not dissimilar from those governing the historical novel: they depict periods perceived to embody significant moments in particular trajectories of history. So, Kingsley sets his novel in fifth-century Alexandria to show the evil roots of Catholicism; Newman's Callista is a rejoinder on the Church's fight against paganism (Bowler 40). These novels are nonetheless interesting for the reconstructive impulse that is visible in them. The architect and designer William Burges wrote that "of all the dreams of archaeologists there is none more frequent than that of endeavouring to transport oneself into the domestic life of any given period" (243). Similarly, novels like Hypatia and Marius the Epicurean are marked by details that apparently confirm their historical accuracy and are full of descriptions of such things as mosaic floorings, jewellery, clothing, cooking pots, drinking vessels and household statuary. This, from The Last Days of Pompeii, is typical:

his tunic glowed in the richest hues of the Tyrian dye, and the fibulae, or buckles, by which it was fastened sparkled with emeralds. Around his neck was a chain of gold, which in the middle of his breast twisted itself into the form of a serpent's head. (27)

Lytton himself frequently steps forward in the narration: "Previous to our description of this house, it may be as well to convey to the reader a general notion of the houses 
of Pompeii [...] we shall endeavour to make this description as clear and unpedantic as possible" (39). This correlates to what, for example, the French classical scholar Gaston Boissier, writing about Pompeii, said of it in 1863: "efforts were directed, above all, to reviving a Roman city that would depict for us the life of bygone ages; it was necessary to see the city in its entirety and in its minutest details in order that the lesson might be complete" (qtd. in Daniel 165). Such stratigraphic culture-history novels, like Boissier's Pompeii, produce archaeological detail in the service of didactics, and the objects signify authenticity - the material guarantees the subjective.

By the early twentieth century we can see a revealing perception of this 'authenticity' in Roger Fry's attack on Lawrence Alma-Tadema, whose work, Fry says, "finds its chief support among the half-educated members of the lower middle class". Specifically he says that in his paintings of classical subject matter AlmaTadema "proceeded to satisfy all the futile inquiries that indolent curiosity might make about the domestic belongings and daily trifles of those people" (666-7). Fry's is a criticism of low-brow taste, and of the Victorians disdained by the Bloomsbury Group, but it also indicates the fascination with 'stuff' rather than ideas, a dismissal of the value of affective continuity and an identification of a whole class of society with the rubbish of mass-produced commodity culture. The 'education' offered by writers like Bulwer-Lytton or painters like Alma-Tadema is not a real education in art or history, as it appeals only to a prurient curiosity that is akin to the wish to see inside their neighbours' houses. In this way, Fry's attack re-states the class anxiety of Victorian museum boards that the lower classes would simply 'gawp' at the exhibits and fail, unless clearly directed, to derive any useful lesson from them. Early museum displays hence did not offer any kind of re-creation of context for their objects, such exhibitions being left entirely to the spectacles of popular culture and to the pages of novels like The Last Days of Pompeii.

Unlike the stratigraphic novel, there is however another category of fiction that registers something of the less controlled effects of the archaeological and in which objects signify very differently. These are the gothic and fantastic fictions of the latenineteenth and early twentieth century, which include texts such as Bulwer Lytton's The Ring of Amasis (1863), Arthur Conan Doyle's “The Ring of Thoth' (1890) and "Lot No. 249" (1894), Bram Stoker's The Jewel of Seven Stars (1903), a number of H. Rider Haggard's short stories and sections of his novels, and Arthur Machen's The Hill of Dreams (1907) as well as others of his stories. Ruth Hoberman has written of what she calls a kind of "museum gothic" (469) in this regard, though I would suggest that such a category is impelled more powerfully by the objects than the museal setting and that the term artefactual fictions would thus seem more applicable. This use of 'artefactual' is one I borrow from Elliott Colla's excellent book on Egyptology where he points to the origin of the word 'artefact' in the distinction between natural and human-made objects, and the emphasis on the status of the object as a product of a process of making. "Most especially" he says "its concept seeks to separate factual questions of what it means to have been made by humans from questions of value" (9). Artefaction, for Colla, is thus the process, or processes, through which the finds of archaeology are constructed through discourse. The museum plays a part in the artefaction, but the objects themselves are not merely passive, rather they are an element within "a sprawling network of agents and actants." As Colla notes, "one indicator of this fact is that even though the processes of artefaction and figuration attempted to construct antiquities as inert matter, the stuff itself often did not obey this command." (19) 
This, then, is the stuff of artefactual fictions, and they contain very different dreams from those of the stratigraphic: disruptive, destructive and even fatal. In these works, the object is not part of a stratum, at home with others in its period, but out of the context of its first existence. They are the mummy in the rooms of the Oxford undergraduate, the ring that once belonged to a priestess now in a museum cabinet, the strangely inscribed shard of pottery in a junk shop: the type is now familiar. The difference from the object in the stratigraphic is that these are conspicuously objects in the present rather than in the past. It is in this that the surface/depth analogy begins to be undone.

Returning to Freud, there is the evident possibility of thinking his work, too, from something like this perspective. Kenneth Reinhard suggests that the appropriation of the archaeological metaphor in Freud, where "the work of psychoanalysis is understood as a therapeutic hermeneutics, process of discovery in which the obscured past is revealed and integrated into the self-present ego," is actually undermined by Freud's own rhetorical deployment of the metaphor (57). In a nice phrase he contrasts what he calls "the Trojan historicism of Anglo-American ego psychology" with the "Orphic archaeology of Lacan"; the latter analyst being not a Schliemann triumphantly uncovering the true meaning of the past, but an Orpheus descending to Hell rather than Troy and always returning empty-handed. As Reinhard puts it, psychoanalysis is then seen "less as the discovery of lost secrets of the unconscious than as the endless re-discovery of the unconscious as lost" (74). The past is always irretrievable.

Discussing how ruins might signify, Reinhard suggests that they are "not so much of the past as to the past": the saxa loquuntur of Freud's essay "speak of something other than the moment which they were intended to represent and always in the foreign and stony tongue of untimely epitaph" (61). This is very different from the dream of the past of the stratigraphic, where objects are firmly of the past - indeed they are what guarantee the reality in those novels. The objects to the past, rather than of it, are the 'new' ones of nineteenth-century culture, the ones that could be described as engaging with the as-yet-unconstituted present. Benjamin echoes the same thought in his assertion that "the true method of making things present is to represent them in our space, not to represent ourselves in their space [. . .] we don't displace our being into theirs, they step into our life" (206).

\section{Objects and Commodities}

This distinction is an important one, and it is in this context that it is possible to turn to a consideration of the archaeological object and to the work of Marx. Marx's would certainly appear to be a much less explicitly archaeological imagination. His own writings do not employ anything like Freud's archaeological metaphors, or indicate that he took any interest at all in the contents of the British Museum, despite working in the Reading Room frequently between his arrival in London 1849 and his death in 1883. This was one of the most intense periods of the Museum's acquisition and expansion during which time many dramatic objects arrived amidst great publicity. ${ }^{4}$ Francis Wheen's biography suggests that "the marvels and monstrosities of Victorian London which so astonished many foreign visitors were invisible to Marx." In contrast to his excitement at seeing an electric model train in a shop window, "had he encountered Dickens' megalosaurus in the mud of Holborn Hill he would," Wheen speculates, "scarcely have given it a second glance" (150-1). Marx's writing is, however, frequently marked by recourse to language that reaches beyond the vocabulary of economics. As Peter Osborne comments: 
Marx draws upon a gothic literary imaginary, in presenting capitalism as secretly possessed by a series of pre-modern forms. But unlike in the gothic, these forms are not residues or remnants of earlier feudal forms, persisting, lurking repressed beneath the surface of modernity. They are the effects of the most advanced economic form itself: capitalism. (16-17)

Again, this is not the past as chronological, but the past as pre-history of the present. That is to say, it is an engagement with the contemporary; specifically here the modernity of capitalism as it transfigures the nineteenth-century world.

Marx elaborates on the process in an appropriately archaeological analogy: "Value [. . . ] transforms every product of labour into a social hieroglyph. Later on men try to decipher the hieroglyphic, to get behind the secret of their own social product" (167). The analogy is appropriate because, like the hieroglyphics of Ancient Egypt (only recently deciphered), this is a secret that, in a sense, everybody knows and has participated in creating, only to forget. It is a secret hidden in plain sight, just as the monuments of Egypt stood for centuries, human-made and visible, yet unreadable. There is nothing 'behind' it, it is present, immanent.

At the same time, Marx famously also uses another analogy from contemporary anthropology: the fetish. In religion, he says "the products of the human brain appear as autonomous figures endowed with a life of their own, which enter into relations both with each other and the human race. So it is in the world of commodities" (165). There is, in this sense, an important distinction between Marx's use of the term and our more common (Freudian) understanding of it. Marx's account is not of fetishism as a psychological condition of the subject, whose desire transforms objects. Rather, it is about the fetish character of the commodity itself, and thus not about the fetishization of particular commodities by certain consumers. Or as Osborne explains: "When he wrote of commodity fetishism Marx wrote not of a desire for commodities, but of a displacement of the desire to know" (21).

In thinking about the objects of archaeology the difficult question concerns their distinctive status as commodities. It is clear that Victorian observers were easily able to see found objects within a framework of commodity culture. They were fascinated by the 'things' of places like Pompeii, often listing them exhaustively as Dickens does: "Lamps, tables, couches, vessels for eating, drinking, and cooking; workmen's tools, surgical instruments, tickets for the theatre, pieces of money, personal ornaments" (446). The tumbled list of objects resembles exactly Dickens' descriptions in his novels of the overflowing materiality of contemporary London. Others make even more explicit comparisons. Frances Trollope, writing in 1842, says: "I shall never feel sent back to ages past by the columns and pediments of ancient Rome as I did by the shop-counters, the oil-jars and the ovens of Pompeii," (261) and forty years later a writer in All the Year Round remarks that "there are traces at Pompeii of all sorts of London shop-things" (44). In both there is an odd reversal of temporality: the present has left its traces in the past.

Virginia Zimmerman has traced the continuity of individual and social relations that the Victorian public imagined with the inhabitants of Pompeii, but it can also be suggested that the striking element in these accounts is not the timeless similarity of human nature, but instead their registering of the extraordinary conditions of capitalist modernity. In these passages the commodity is the means by which the present and the past are negotiated. The unreadable, unknowable past is made knowable by imagining it as identical to contemporary commodity capitalism. The 
objects that figure in nineteenth-century artefactual fictions are apparently from outside a recognisable structure - that is, their mode of production is radically other than that which obtains in the present - but they are nevertheless produced. In this way, these kinds of fictions negotiate objects into their own commodity culture by the initial recognition and then the denial or forgetting of such objects as having been the product of labour.

Nineteenth-century writers also recognised the ways in which artefaction happens in the movement from use value to exchange value. This is from an 1852 article on a display of objects from Pompeii in Household Words:

In the next cupboard are various articles of a domestic nature: soap, cotton, sponges, wax...the vanity of human toil sowing where it is never to reap; the cunning of mankind intent upon a morrow which will never arrive; the value of small things; the worthlessness of great ones -how many lessons are taught by these relics, the whole of which would not probably have purchased for their possessor a night's rest, or a meal, but for the possession of which the connoisseur would now-a-days mortgage his broad lands and entail poverty on his descendants? (Lewis 283)

As well as the more familiar meditation on the vanity of human ambition, this observation illustrates the transition in the status of objects. The use value of the trivial objects is translated into exchange value and the connoisseur is thereby prepared to abandon the traditional feudal system of leaving his broad lands to his descendants by entering into the illusory economy of commodity culture, trading solid land for evanescent 'value'. The Romanticism of the antiquarian reverie is replaced by a heartless plunge into capitalist economics.

Despite their antiquity, the soap and wax of Pompeii or the cups and beads of Troy are ordinary and recognisable items, but there are other kinds of objects that are more difficult to recognise in such straightforward ways, such as those of religious or ritual usage, or without any apparent function at all. Marx is clear that these too are commodities:

Circulation becomes the great social retort into which everything is thrown, to come out again as the money crystal. Nothing is immune from this alchemy, the bones of the saints cannot withstand it, let alone more delicate res sacrosanctae, extra commercium hominum (consecrated objects, beyond human commerce). Just as in money every qualitative difference between commodities is extinguished, so too for its part, as a radical leveller, it extinguishes all distinctions. (229)

For Marx, as is apparent in this passage and re-stated frequently in his work, there is no differentiation between commodities. In this, however, he perhaps over-states the totalising and destructive power of capital, for it would seem obvious that there is in fact a significant difference between a bar of soap and an Assyrian winged bull. Nonetheless, there is a possible indication of another way to read the difference of the characteristic objects of artefactual fictions to be found in Capital: the magical rings, the strange statues, the mysterious boxes of Victorian gothic. In Chapter 2 Marx asserts that "commodities are things, and therefore lack the power to resist man. If they are unwilling, he can use force; in other words he can take possession of them" (178). There is an odd contradiction in Marx's words here: commodities both lack 
power but can be 'unwilling'. Here I think, is what makes archaeological objects different kinds of commodities from tables or coats: it is their greater 'unwillingness': a stronger resistance to the process of commodification that necessitates the greater 'use of force'.

This push-and-pull of unwillingness and taking possession correlates with the struggle apparent in processes of artefaction. Neither commodification nor artefaction are ever 'completed' in the sense that a permanent stasis of condition is never achieved. The dream is one of the markers that this struggle is taking place, as the figure of the dream frequently indicates, or attempts not to indicate, the presence of labour or money. Nineteenth-century archaeological texts are, in this way, marked by a doubleness of discourse in which both labour and money are emphasised alongside a vanishing of both in the language of wonder, miracle, luck, fate and magic and dreams. To take Austen Layard's best-seller Nineveh and Its Remains: every discovery is framed by comments on the presence of the workmen, the carrying of baskets of earth and the shifting of quantities of rubble. The accompanying illustrations emphasise the mechanical difficulties and the heavy work of extracting and moving the larger finds. This labour, however, is erased even as it is being performed. In Layard's account of his

excavations at Nineveh he writes of being unable to sleep on the night before the digging began:

Visions of palaces under-ground, of gigantic monsters, of sculptured figures, and endless inscriptions, floated before me. After forming plan after plan for removing the earth, and extricating these treasures, I fancied myself wandering into a maze of chambers from which I could find no outlet. Then again, all was reburied and I was standing on the grass-covered mound. (Remains 25)

In the dream too, objects simply appear or, indeed, seem to excavate themselves. Layard describes, "this gigantic head, blanched with age, thus rising from the bowels of the earth...slowly ascending from the regions below" (Remains 98). The dream takes the place of the work that is to be performed in a fantasy of doing without the difficult reality of local labour.

Nick Shepherd calls this a disciplinary "habit of elision" in the context of twentieth-century African archaeology, where he suggests that "a concern with native labour, its tractability, its cost, its continued supply, runs as a thread through colonial and apartheid histories" and argues that this is precisely mirrored in archaeological site reports (346-7). Although there are clearly further racial dimensions to this habit of elision in a colonial situation, the language is identical to that deployed about the British working class in the nineteenth century. In the 1840s and 1850s, when Layard and others are making their expeditions abroad, the tractability of workers at home had become a crucial issue in the context of the booms and busts of early industrialisation. Arguably, the archaeological habit of elision was one already acquired long before any digging took place. Shepherd explores Ian Hodder's observation of a shift in the style and rhetoric of the archaeological site report, noting the latter's claims that early examples of the genre give actor-oriented accounts and make use of personal pronouns, whereas in the late nineteenth century a "transformation occurs towards more distant, abstract, decontextualized accounts" and the use of the passive voice (Hodder 271). My argument is that such 'scientising' of archaeological language is to some extent only formalising, however, what is already present in the earlier and 
apparently more romantic accounts. The earlier versions of the habit of elision is established in the language of the dream, the vision and magic.

The archaeologist dreaming the objects into existence is slid together with an idea of the objects themselves having been asleep: "All these figures, the idols of a religion long since dead and buried like themselves, seemed actually in the twilight to be raising their desecrated heads from the sleep of centuries"(Remains 369). In their sleep they too have something like the capacity to dream themselves into existence. In his Arcades Project Benjamin writes of an aspect of the life of the commodity, which is the boredom it experiences in its wait to be sold (861). What wakes it is its entrance into an economy of exchange, just as what animates the archaeological object is its coming into being as a commodity. In Victorian artefactual fictions, this awakening, though, marks the moment of the disturbance of the present, in which the object resists its commodification and asserts itself as a product of human labour.

It is not only the effacement of labour that takes place in these accounts, but also a curious disappearance of the 'taking possession' that Marx refers to. No-one seems to wish to assert ownership of the objects found, that is, no-one wishes to articulate the object as commodity, to display the 'force' of taking possession. Belzoni, for example, presents a very confusing account of the financing and purpose of his travels in Egypt. He claims to have been solely "making researches for antiquities, which were to be placed in the British Museum," (37) yet some objects are given personally as presents to him, while some he purchases directly or indirectly with money that comes from Henry Salt, the consul-general who, in turn, may or may not be acting for the British government or the Museum. In Layard's autobiography, there is a strikingly similar passage. Belzoni begins his version of events: "It has been erroneously stated that I was regularly employed by Mr Salt [ . . . I positively deny that I was ever engaged by him" (37); and Layard "It was generally believed In England that the expenses of my first journey to Mosul, and of the excavations previous to the grant made by the British Museum for continuing my researches - of which I did not avail myself until the month of October 1846 - were entirely borne by Sir Stratford Canning. Such was not the case" (1:155). There then follows a series of confusing acknowledgments of debts to Canning, Layard's mother and the Museum. He concludes: "I might have claimed all that I found in the ruins as my own property" (156), but he emphatically does not make such a claim. Much as this may reflect the precarious pecuniary reality of those early expeditions, the effect is a dispersal of agency in which no one person is responsible for the possession of the finds. Hence, after its self-excavation, the object then seems to take itself to the market, as the commodity does.

In a poem published in Household Words, a bull at Smithfield Market addresses his "cousin of Nineveh":

whether you be there, or here,

Or on your travels

and continues:

your high mission

To Fifty One's Great Exhibition,

Is not to show your ancient learning,

But into practice knowledge turning (589-90) 
It is not a good poem, but in its clumsiness it exposes the tangled idea of the selfmarketing commodity. The Nineveh bull is travelling to England independently on its mission and is cousin to one already in the marketplace. Moreover, the bull is not actually coming to Smithfield but, both topically and inaccurately, to the Great Exhibition of 1851 (the poem was published just before its opening). Its destination is telling; rather than presenting itself at the very old marketplace of the pre-capitalist economy, the bull is going to the Great Exhibition, the absolutely new spectacular space that established the commodity as "the centrepiece of everyday life, the focal point of all representation, the dead centre of the modern world" (Richards 1).

In their reluctance to assert possession, the archaeologists underscore again the denial of production and commodification: objects are 'finds' or 'discoveries', that eventually become 'gifts' or 'bequests' or 'acquisitions'. As Susan Stewart notes, this is characteristic: the collection, she says:

represents a metaphor of 'production' not as 'the earned' but as 'the captured'[. . .] the collection says that the world is given; we are the inheritors, not the producers of value here [. . .] The collector constructs a narrative of luck which replaces the narrative of production. (164-5)

Again, Layard provides an illustration:

It had often occurred to me during my labours, that the time of the discovery of these remains was so opportune, that it might be looked upon as something more than accidental [. . . I It was consequently just at the right moment that they were disinterred; and we have been fortunate enough to acquire the most convincing and lasting evidence of that magnificence, and power, which made Nineveh the wonder of the ancient world. (Popular 351)

Even as he mentions his "labours" he invokes good fortune as that which has really brought the things into the world and by referring to them as "evidence" he rhetorically places them in the system of knowledge. They are to be made safe, inert artefacts by their position within a system of relations constructed by the new 'knowledge' of archaeology, the mirror of the abstract system of relations that the commodity inhabits.

\section{Residues of a Dream World}

It is important to return finally to Freud and to Benjamin. Writing in the 1930s, the dream became an important idea for Benjamin in his effort to understand the prehistory of the present. In particular, he endeavours to connect Marx and Freud through this figure, suggesting that:

Didn't Marx teach that the bourgeoisie, as a class, can never arrive at a perfectly clear awareness of itself. And if this is the case, isn't one justified in annexing to Marx's thesis the idea of the dream collective (that is, the bourgeois collective)? (863)

Similarly, the Arcades Project suggests that the spectacular spaces of the nineteenth century are both profoundly connected to and manifestations of this dream collective:

Museums unquestionably belong to the dream houses of the collective [. . .] 
the inside of the museum appears as an interior magnified on a giant scale, In the years 1850-1890, exhibitions take the place of museums. (406-7)

Museums and exhibitions are the "residues of a dream world" (898), and as Richards reminds us, "in the spectacle, production and consumption are paired moments in a single process of commodity representation" (16).

The dreaming collective knows no history. Events pass before it as always identical and always new. The sensation of the newest and most modern is, in fact, as much a dream formation of events as the 'eternal return of the same'. The perception of space that corresponds to this perception of time is superimposition. (854-55)

There is a strong echo of this conception in Freud too, where late in his life he still persisted with the analogy of archaeology, despite more or less rejecting it each time he uses it. In "Civilization and Its Discontents" (1930), for example, he asks the reader to imagine that:

Rome is not a place where people live, but a psychical entity with a similarly long, rich past, in which nothing that ever took shape has passed away, and in which all previous phases of development exist beside the most recent [. . .] and the observer would perhaps need only to shift his gaze or his position in order to see the one or the other. (8-9)

In the next line he dismisses this fantasy as "pointless," unimaginable and absurd. Yet, despite this dismissal he returns immediately to the analogy, only to "readily" dismiss it once again ("Civilization"10). His persistence indicates that there is nevertheless something about the metaphor that is true, and it is the dream that figures the possibility that, contrary to his assertion, the same space can accommodate two different things. That space $i s$ the archaeological, in fiction, culture and documentary accounts.

The archaeological theorist Gavin Lucas proposes that "archaeology is a materialising activity - it does not simply work with material things, it materialises. It brings new things into the world; it reconfigures the world" (117). This, of course, runs counter to the more usual sense of what archaeology does, which is recovering old things, recognising those things for what they 'really are' and placing them in a context. But these 'new' things are not new in that they already exist, or have existed before; their newness comes about during and after having been brought into the present. Lucas suggests a definition of archaeology as "an engagement with the unconstituted present." (117). In this sense, archaeology is not the simple recovery and understanding of the past, but the negotiation of objects into the present and the simultaneous negotiation of that present itself. This is the doubled space, and these, then, constitute the dreams of nineteenth-century archaeology. The disturbance produced by archaeological objects is not the horror of the past, but of the recognition of the conditions of the present. The dreams of the archaeological imagination are not the dreams of Freud, but the dreams of capitalist modernity. 


\section{Notes}

1. Baron Vivant Denon was invited by Napoleon as an artist to accompany other scholars alongside the army in Egypt. He later became Director General of Museums in France.

2. There is an exhaustive list of texts discussing the topic in Ucko 271-2.

3. Glyn Daniel suggests that Nabonidus, the last King of Babylon (556-539 $\mathrm{BCE}$ ), may have been the earliest deliberate 'archaeologist'. (16)

4. In the $1850 \mathrm{~s}$ alone, the British Museum received large and spectacular material from Layard's second expedition to Mesopotamia, Charles Newton's excavations at Halicarnassus, and Nathan Davis's in Carthage. 


\section{Works Cited}

“A Last Day at Pompeii." All the Year Round 35 (1884): 41-45.

Beer, Gillian. Darwin's Plots. Evolutionary Narrative in Darwin, George Eliot and Nineteenth-Century Fiction. Cambridge: Cambridge UP, 1983.

Belzoni, Giovanni Battista. Travels in Egypt and Nubia. Italy: White Star, 2007.

Benjamin, Walter. The Arcades Project. Ed. Rolf Tiedemann. Trans. Howard Eiland and Kevin McLaughlin. Cambridge, Mass. Belknap, 1999.

Bowler, Peter J. The Invention of Progress: The Victorians and the Past. Oxford: Blackwell, 1989.

Bulwer-Lytton, Edward. The Last Days of Pompeii. London: Odhams Press, n. d.

Burges, William. "Review of the Japanese court of the International Exhibition." Gentleman's Magazine 9 (1862): 243-54.

Carter, Howard, and A.C. Mace, The Tomb of Tut-ankh-amen. London: Cassell, 1923.

Ceram, C.W. Hands on the Past, New York: Alfred Knopf, 1966.

Colla, Elliott. Conflicted Antiquities:Egyptology, Egyptomania, Egyptian Modernity. Durham NC.: Duke UP, 2007.

Daniel, Glyn. 150 Years of Archaeology. London: Duckworth, 1975.

Dickens, Charles, American Notes and Pictures From Italy, London: Dent, 1997.

Freud, Sigmund. Letters of Sigmund Freud. Ed. Ernst L. Freud. Trans. Tania and James Stern. New York: Basic Books, 1960.

---. "Letter to Romain Rolland (A Disturbance of Memory on the Acropolis)." On Murder, Mourning and Melancholia. Trans. Shaun Whiteside. London: Penguin, 2005. 233-244.

---. "The Aetiology of Hysteria." Standard Edition of the Complete Works. Vol. 3. London: Vintage, 2001. 189-224.

Fry, Roger. 'The Case of the Late Sir Lawrence Alma-Tadema, O.M.', The Nation, 18 (1913): 666-7.

Gay, Peter. Freud: A Life for Our Times. New York: W.W. Norton, 1988.

Hoberman, Ruth. "In Quest of a Museal Aura." Victorian Literature and Culture. 31:2 (2003): 467-482.

Hodder, Ian "Writing Archaeology: Site Reports in Context." Antiquity 63 (1989): 268-74.

Kuspit, Donald. "A Mighty Metaphor: The Analogy of Archaeology and Psychoanalysis." Sigmund Freud and Art: His Personal Collection of Antiquities. Eds. Lynn Gamwell and Richard Wells. London: Freud Museum, 1989. 133-151.

Layard, Austen Henry. A Popular Account of Discoveries at Nineveh. New York: Harper and Brothers, 1854.

---. Autobiography and Letters. London: John Murray, 1903. 2 vols.

---. Nineveh and Its Remains. London: John Murray, 1849.

Lewis, John Delaware. "Preservation in Destruction." Household Words 5 (1852): 280-284.

Lucas, Gavin. "Modern Disturbances: On the Ambiguities of Archaeology." Modernism/Modernity. 11:1 (2004): 109-20.

Marx, Karl. Capital. London: Penguin, 1976.

Osborne, Peter. How to Read Marx. London: Granta, 2005.

Reinhard, Kenneth. "The Freudian Things: Construction and the Archaeological Metaphor." Excavations and Their Objects. Ed Stephen Barker. New York: SUNY UP, 1996. 57-80. 
Richards, Thomas. The Commodity Culture of Victorian England. London: Verso, 1991.

Schliemann, Heinrich, Ilios. The City and Country of the Trojans. New York: Harper and Brothers, 1881.

Shepherd, Nick. "“When the Hand that Holds the Trowel is Black...': Disciplinary Practices of Self-Representation and the Issue of 'Native' Labour in Archaeology." Journal of Social Archaeology 3 (2003): 333-52.

"The Smithfield Bull to His Cousin of Nineveh." Household Words 51 (1851): 589-90.

Stewart, Susan. On Longing. Narratives of the Miniature, the Gigantic, the Souvenir, the Collection. Durham, NC.: Duke UP, 1993.

Thomas, Julian. Archaeology and Modernity. London: Routledge, 2004.

Trollope, Frances. A Visit to Italy London: Richard Bentley, 1842.

Ucko, Peter. "Unprovenanced Material Culture and Freud's Collection of Antiquities." Journal of Material Culture 6 (2001): 269-232.

Wheen, Francis. Karl Marx. London: Fourth Estate, 2000.

Williams, Rosalind. Notes from the Underground. Cambridge, Mass.: MIT Press, 2008.

Young, Robert. Darwin's Metaphor: Nature's Place in Victorian Culture. Cambridge: Cambridge UP, 1985.

Zimmerman, Virginia. Excavating Victorians. New York: SUNY UP, 2008. 